\title{
The Major Outer Membrane Protein Oprf is Required for Rhamnolipid Production in Pseudomonas aeruginosa
}

\begin{abstract}
Emeline Bouffartigues ${ }^{1}$, Gwendoline Gicquel ${ }^{1}$, Alexis Bazire ${ }^{2}$, Laurène Fito-Boncompte ${ }^{1,2}$, Laure Taupin ${ }^{2}$, Olivier Maillot ${ }^{1}$, Anne Groboillot ${ }^{1}$, Cécile Poc-Duclairoir ${ }^{1}$, Nicole Orange ${ }^{1}$, Marc Feuilloley ${ }^{1}$, Alain Dufour $^{2}$ and Sylvie Chevalier ${ }^{1 *}$

${ }^{1}$ Laboratoire de Microbiologie du Froid Signaux et Micro-Environnement EA 4312, Normandie Sécurité Sanitaire et Environnementale, Université de Rouen, France

${ }^{2}$ Laboratoire de Biotechnologie et Chimie Marines, EA 3884. Université de Bretagne-Sud, Université Européenne de Bretagne, France

\section{Summary}

The OprF porin is the major outer membrane protein of bacteria belonging to the Pseudomonas genus, and is partially exposed on the cellular surface. A study based on the comparison between $P$. aeruginosa $\mathrm{H} 103$ and its oprFdeficient mutant led to the finding that the absence of OprF abolished swarming but not swimming and twitching motilities. These phenotypes were explained at least in part by the inability of the oprF mutant to produce biosurfactant rhamnolipids. The levels of mRNAs encoding the rhamnolipid biosynthetic enzymes RhIA and RhIB were strongly decreased in the absence of OprF, indicating that rhamnolipid production was impaired at the transcriptional level. We suggest that the presence of OprF in the outer membrane of $P$. aeruginosa is required for environments colonization, making thus OprF a serious target for limiting $P$. aeruginosa spreading in case of cystic fibrosis.
\end{abstract}

Keywords: OprF; Porin; Rhamnolipid; Motility; Pseudomonas

Abbreviations: LC/MS: Liquid chromatography coupled to Mass Spectrometry

\section{Introduction}

Pseudomonas aeruginosa tis an ubiquitous germ known as an important opportunistic pathogen of humans, causing a variety of infections among which chronic lung infections in cystic fibrosis patients [1-3]. Pseudomonas members are also described for their striking ability to adapt to various ecological niches [4]. This versatility requires a particularly well developed ability to adapt to changes of environmental conditions, to which proteins of the outer membrane may contribute, due to their partial exposition at the cell surface. Among them, OprF is one of the very few general porins [5], allowing non-specific diffusion of ionic species and of small polar nutrients [6]. OprF is also a major structural protein, anchoring the outer membrane to the peptidoglycan layer $[7,8]$. It is necessary for adaptation to various environments since it allows growth in low-osmolarity conditions [8], is over-produced in high salinity condition [9] and in ASM medium, which mimics the lung environment during cystic fibrosis [10]. It allows also the bacteria to respond to temperature variations by modulating the outer membrane permeability through a change in channel size [11]. OprF has been furthermore involved in adhesion to eukaryotic cells [12], and in biofilm formation under anaerobic conditions [13] enabling microcolonies formation [10]. Finally, we have recently shown that OprF is required for full virulence expression [14].

P. aeruginosa displays three types of motility: swimming in liquid or at low agar concentrations, twitching on solid surfaces, and swarming on semisolid media. Swimming and twitching result from the polar flagellum of $P$. aeruginosa and type IV pili, respectively, whereas swarming depends on both appendages and of rhamnolipids [15-17]. Rhamnolipids are biosurfactants composed of mono- or di-rhamnose linked to the lipid components 3-(3-hydroxyalkanoyloxy) alkanoic acids (HAAs) $[18,19]$. These glycolipids play a central role in swarming motility by acting as surface-modifying agents [20]. They can enhance cell surface hydrophobicity, by inducing LPS release from the outer membrane [21] and by adsorbing onto the cell surface [22,23], which can in turn modify the bacterium-substratum interactions. They affect biofilm formation through microcolonies formation, motility [24], maintaining fluid channels between mushroom-like structures [25], and mediating cell detachment from biofilms [26]. Recently, rhamnolipids have been furthermore suggested to act as protective agents of $P$. aeruginosa against polymorphonuclear leukocytes, functioning as a biofilm shield in vivo [27,28].

Since bacterial motility plays a key role in the bacterial adaptation to environments, especially in surfaces colonization, we further investigated the function of OprF in P. aeruginosa motility. In this study, we show that an $o p r F$ knock out leads to impaired swarming, but not swimming or twitching motilities, at least partly through a deep alteration in rhamnolipid production.

\section{Materials and Methods}

\section{Bacterial strains and growth conditions}

The strains were P. aeruginosa $\mathrm{H} 103$ (PAO1 prototroph), its oprF mutant $\mathrm{H} 636$ obtained by homologous recombination with an oprF fragment containing a streptomycin cassette [29], and H636O, which corresponds to H636 complemented by plasmid pRW5 (encoding carbenicillin resistance) consisting in the functional oprF gene from $P$. aeruginosa $\mathrm{H} 103$ cloned into pUCP19 [14,30]. Cultures were inoculated at an initial $\mathrm{OD}_{600}$ of 0.07 , and bacteria were grown at $37^{\circ} \mathrm{C}$ on a rotary shaker $(180 \mathrm{rpm})$ in Luria Bertani (LB) broth. In complement, $500 \mu \mathrm{g}$ streptomycin $\mathrm{mL}^{-1}$ only or with $300 \mu \mathrm{g}$ carbenicillin $\mathrm{mL}^{-1}$ were added in $\mathrm{H} 636$ and $\mathrm{H} 636 \mathrm{O}$ cultures, respectively.

*Corresponding author: Sylvie Chevalier, Laboratoire de Microbiologie du Froid, Signaux et Micro-environnement, 55 rue St Germain, 27000 Evreux, France, Tel: (+33) 2.32.29.15.60; Fax: (+33) 2.32.29.15.50; E-mail: sylvie.chevalier@univrouen.fr

Received May 11, 2011; Accepted June 15, 2011; Published June 25, 2011

Citation: Bouffartigues E, Gicquel G, Bazire A, Fito-Boncompte L, Taupin $\mathrm{L}$, et al. (2011) The Major Outer Membrane Protein Oprf is Required for Rhamnolipid Production in Pseudomonas aeruginosa. J Bacteriol Parasitol 2:118. doi:10.4172/2155-9597.1000118

Copyright: (c) 2011 Bouffartigues E, et al. This is an open-access article distributed under the terms of the Creative Commons Attribution License, which permits unrestricted use, distribution, and reproduction in any medium, provided the original author and source are credited. 
Citation: Bouffartigues E, Gicquel G, Bazire A, Fito-Boncompte L, Taupin L, et al. (2011) The Major Outer Membrane Protein Oprf is Required for Rhamnolipid Production in Pseudomonas aeruginosa. J Bacteriol Parasitol 2:118. doi:10.4172/2155-9597.1000118

Page 2 of 5

\section{Motility assays}

These assays were essentially performed as described by Rashid \& Kornberg [31]. Briefly, LB plates containing $0.3 \%$ agar were point inoculated with a toothpick and incubated for 24 hours at $37^{\circ} \mathrm{C}$. Swimming was quantified by measuring the circular turbid zone. The swarming assay was identical, except that LB plates contained $0.5 \%$ agar and were incubated for $48 \mathrm{~h}$. For twitching assays, cells were stab inoculated to the bottom of the Petri dish through a thin $(\sim 3 \mathrm{~mm}) \mathrm{LB}$ agar layer (1\% agar). After incubation at $37^{\circ} \mathrm{C}$ for $48 \mathrm{~h}$, the agar was removed, the Petri dish was washed with a stream of tap water, and the cells attached to the polystyrene surface were stained with crystal violet $(1 \% \mathrm{w} / \mathrm{v})$ solution. Each assay was made at least in triplicate.

\section{Phage PO4 sensitivity assay}

$10 \mu \mathrm{L}$ of lysates that contain 102 plates forming units (PFU) of phages was mixed with 107 colonies forming units (CFU) of $\mathrm{P}$. aeruginosa cells grown to OD600 of 0.7 and resuspended in $100 \mu \mathrm{L}$ of LB. After $10 \mathrm{~min}$ of incubation, $3 \mathrm{~mL}$ of top agar was added, and the mixture was plated. Numeration of plaques was made after 16 to $24 \mathrm{~h}$ of incubation at $37^{\circ} \mathrm{C}$.

\section{Rhamnolipid quantification}

The drop-collapse test was performed as previously described [32]. Rhamnolipids were further extracted and analyzed by liquid chromatography coupled to mass spectrometry (LC/MS) as previously described [33].

\section{Quantitative RT-PCR}

Extraction of RNAs, synthesis of cDNAs and real time PCR were achieved as previously described [9] using primers described in Table 1. PCR reactions were performed in triplicate and the standard deviations were lower than $0.15 \mathrm{CT}$. The relative quantification of the mRNAs of

\begin{tabular}{|c|c|c|}
\hline Gene & sequences (5'-3') & References \\
\hline$r h / A$ & $\begin{array}{l}\text { F: GATCGAGCTGGACGACAAGTC } \\
\text { R: GCTGATGGTTGCTGGCTTTC }\end{array}$ & $\begin{array}{l}{[33]} \\
{[33]}\end{array}$ \\
\hline$r h / B$ & $\begin{array}{l}\text { F: GAACAGGCAGACCACGCC } \\
\text { R: CGCATCTTCACCCAATGGAT }\end{array}$ & $\begin{array}{l}{[33]} \\
{[33]}\end{array}$ \\
\hline$r h / C$ & $\begin{array}{l}\text { F: ACCGGATAGACATGGGCGT } \\
\text { R: GATCGCTGTGCGGTGAGTT }\end{array}$ & $\begin{array}{l}{[33]} \\
{[33]}\end{array}$ \\
\hline pilA & $\begin{array}{l}\text { F: ATTGCCATTCCCCAGTATCAGA } \\
\text { R: CGAAGCACCTTCCGAACG }\end{array}$ & $\begin{array}{l}\text { This study } \\
\text { This study }\end{array}$ \\
\hline flic & $\begin{array}{l}\text { F: CTCGGAAAACGCTACCAACG } \\
\text { R: GCGAAGTCGGTGTCCTTGAT }\end{array}$ & $\begin{array}{l}\text { This study } \\
\text { This study }\end{array}$ \\
\hline estA & $\begin{array}{l}\text { F: GGTTGGCCATGCCTTCCT } \\
\text { R: ACGTCATTCCGTTGAACATCC }\end{array}$ & $\begin{array}{l}\text { This study } \\
\text { This study }\end{array}$ \\
\hline $16 S$ & $\begin{array}{l}\text { F: CAGGATTAGATACCCTGGTAGTCCAC } \\
\text { R: GACTTAACCCAACATCTCACGACAC }\end{array}$ & $\begin{array}{l}{[35]} \\
{[35]}\end{array}$ \\
\hline
\end{tabular}

Table 1: Primers used in quantitative RT-PCR experiments.

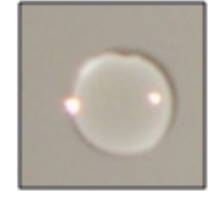

H103

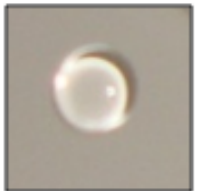

H636

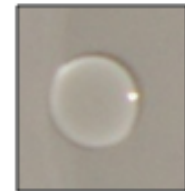

H636O

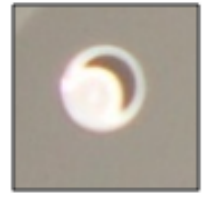

$\mathrm{H}_{2} \mathrm{O}$
Figure 1: Drop-collapse test performed by adding $10 \mu \mathrm{L}$ of culture supernatants of the indicated strains $(48 \mathrm{~h})$ to water drops $(20 \mu \mathrm{L})$ on glass slides. interest was obtained by the comparative CT $\left(2^{-\Delta \Delta C T}\right)$ method [34], using $16 \mathrm{~S}$ rRNA as endogenous control [35]. $\triangle \mathrm{CT}$ values were calculated by subtracting the $16 \mathrm{~S}$ rRNA CT value from the CT value of an mRNA of interest from the same sample. $\Delta \mathrm{CT}$ values were then obtained by calculating the difference between: i) the $\triangle \mathrm{CT}$ value of a given mRNA resulting from $P$. aeruginosa $\mathrm{H} 636$ cells grown to a specific stage, and ii)

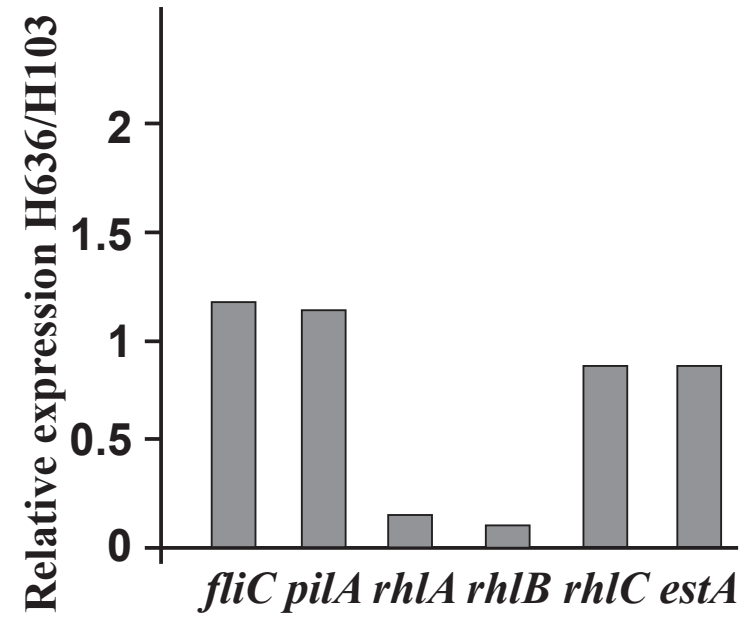

Figure 2: Expression levels of the indicated genes in the oprF mutant $\mathrm{H} 636$, relatively to $\mathrm{P}$. aeruginosa $\mathrm{H} 103$. mRNAs were assayed by quantitative RT-PCR performed on RNA extracted from $\mathrm{H} 636$ and $\mathrm{H} 103$ strains. Values above and below 1 show a higher and a lower mRNA level in $\mathrm{H} 636$ than in $\mathrm{H103}$, respectively. PCR reactions were performed in triplicate and the standard deviations were lower than 0.15 CT. The experiments were performed twice with independent bacterial cultures.

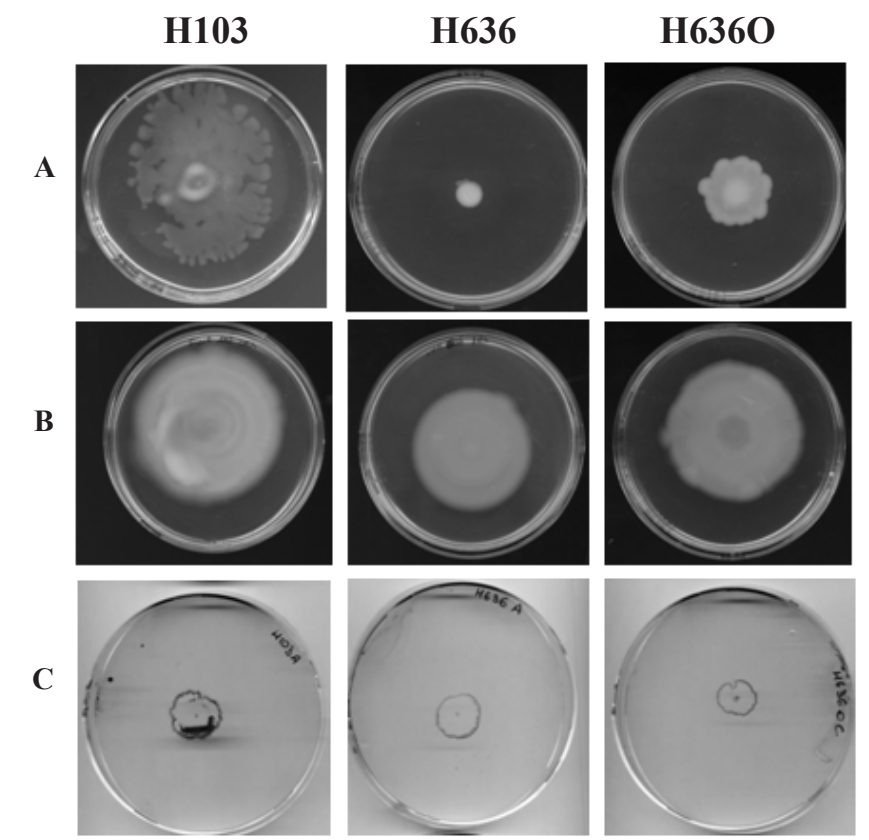

Figure 3: Swarming $(A)$, swimming $(B)$ and twitching $(B)$ motilities of $P$. aeruginosa strains $\mathrm{H} 103$ (wild type), H636 (oprF mutant), and H636O (complemented oprF mutant). 
the $\triangle \mathrm{CT}$ value of the same mRNA from P. aeruginosa H103 (wild type) cells grown to the same stage. Relative mRNA level values are equal to $2^{-\Delta \triangle C T}$ : values above and below 1 show a higher and a lower mRNA level in the oprF mutant $\mathrm{H} 636$ than in the wild type strain, respectively (eg a value of 0.5 indicates that the mRNA level was divided by 2 in H636).

\section{Results}

Three strains were compared in this study: the P. aeruginosa H103 wild type strain, its oprF mutant H636, and the oprF-complemented mutant strain H636O. The three growth curves obtained in LB medium at $37^{\circ} \mathrm{C}$ with shaking were similar, with a doubling time of $45 \mathrm{~min}$ [14].

\section{Swarming is altered in the oprF mutant}

The oprF mutant was unable to swarm, and the complementation of H636 with the oprF gene restores partially the swarming ability (Figure 1A). Swimming and twitching were slightly but not significantly altered (Figure 1B \& Figure 1C), suggesting that both flagella and type IV pili were functional. To further dissect the swarming motility deficiency phenotype, quantitative RT-PCR experiments were performed to assay the transcription level of $f l i C$ and pilA genes, encoding the main flagellum and type IV pilus subunits, respectively. Figure 2 showed that their expression were not significantly down-regulated in the oprF mutant compared to H103 strain. The functionality of type IV pili was furthermore assayed by infecting the strains with the $\mathrm{PO} 4$ phage, which uses type IV pili as receptors [36]. The three strains were similarly sensitive to phage PO4 (the number of lysis plates being similar), indicating that type IV pili were present and functional in the H636 oprF mutant.

\section{OprF is required for rhamnolipid production}

Since swarming is depending on type IV pili, flagella and rhamnolipids [17], we next searched for the ability of the oprF mutant to produce these major biosurfactants. To achieve this rapidly, we first used the drop collapse test as previously described [32]. As shown on Figure 3, the drop spreading out in case of $\mathrm{H} 103$ and $\mathrm{H} 636 \mathrm{O}$ suggested that biosurfactants were present. This was not the case for H636, suggesting a lack or a reduction in the biosurfactants amount. In supernatants of stationary phase cultures of the wild type strain, ten different ionic species, corresponding up to twelve rhamnolipids species, were identified by LC/MS (Table 2). Extra-cellular rhamnolipid production by the oprF mutant was nearly abolished: only three ionic species $(m / z 675,677$, and 705$)$ were detected in H636 supernatants, but in 25 to 50 -fold lower amounts than in H103 supernatants (Table
2). Furthermore, the non detection of the ionic species $m / z 649$ in $\mathrm{H} 636$ supernatants indicated that Rha-Rha-C10-C10 production dropped more than 500 fold in the absence of OprF. We observed similar results when assaying rhamnolipids from supernatants of 48 and $72 \mathrm{~h}$ cultures (data not shown), thereby ascertaining that production of extra-cellular rhamnolipids by the oprF mutant is dramatically impaired, and not only delayed. The complementation of the mutation restored an efficient extra-cellular production of all rhamnolipid species, since their amounts were only 1.1 to 2.6-fold lower than in H103 supernatants (Table 2).

\section{rhlAB expression is altered in the absence of $\mathrm{OprF}$}

To investigate whether the production of extra-cellular rhamnolipids by the oprF mutant is impaired at the biosynthesis or at the secretion level, we assayed rhamnolipids from bacterial pellets. A defect in rhamnolipid secretion was expected to lead to higher rhamnolipid accumulation in H636 OprF-negative cells than in H103 cells. This was however not the case (Table 2, intra cellular amounts), suggesting that the main defect occurred at the biosynthesis level. Mono-rhamnolipid biosynthesis specifically requires the successive actions of the enzymes RhlA and RhlB, encoded by the operon rhlAB [37,38]. Di-rhamnolipids are synthesized from mono-rhamnolipids by a third enzyme, the rhamnosyltransferase 2 RhlC [39]. Rhamnolipid production furthermore requires the autotransporter esterase EstA, the role of which remains unknown [40]. We therefore examined by quantitative RT-PCR whether the expression of these genes was affected in the oprF mutant. Whereas $r h l C$ and est $A$ mRNA levels were not significantly reduced in H636 mutant compared to H103 wildtype strain, the rhlA and rhlB mRNA levels were respectively 4.6 and 9-fold lower than in $\mathrm{H} 103$ (Figure 2). The down-regulation of the rhlAB operon seems strong enough to explain the rhamnolipid biosynthesis defect of the oprF mutant.

\section{Discussion}

OprF is the major outer membrane protein, partially exposed to the cell surface. Our study enabled us to find evidences for the involvement of OprF in swarming, but not in swimming and twitching motilities. Transcription of $f l i C$ and pilA genes are not affected, and the sensitivity to phage $\mathrm{PO}_{4}$ indicates that the retraction function required for phage infection is maintained on the $o p r F$ mutant cell surface [16]. Taken together, these results suggest that flagella and type IV pili are expressed and functional in the oprF mutant. Since rhamnolipids are known to play a central role in swarming through their surfactant properties $[20,41,42]$, we then focused on their production. Consistently, we found

\begin{tabular}{|c|c|c|c|c|c|c|c|}
\hline \multirow[t]{2}{*}{ Rhamnolipid } & \multirow[t]{2}{*}{ Ionic species* $(\mathrm{m} / \mathrm{z})$} & \multicolumn{3}{|c|}{$\begin{array}{c}\text { Extra cellular amount } \dagger \\
\left(10^{4} \text { Area } / \mathrm{OD}_{600}\right)\end{array}$} & \multicolumn{3}{|c|}{$\begin{array}{c}\text { Intra cellular amount } \\
\left(10^{4} \text { Area } / O D_{600}\right)\end{array}$} \\
\hline & & H103 & $\mathrm{H} 636$ & $\mathrm{H} 636 \mathrm{O}$ & $\mathrm{H} 103$ & H636 & $\mathrm{H} 636 \mathrm{O}$ \\
\hline Rha-C10-C10 & 503 & $12.3 \pm 1.1$ & ND & $11.3 \pm 1.9$ & ND & ND & ND \\
\hline Rha-C10-C12:1 & 529 & $3.9 \pm 0.2$ & ND & $2.2 \pm 0.3$ & ND & ND & ND \\
\hline $\begin{array}{l}\text { Rha-C12-C10 } \\
\text { Rha-Rha-C8-C10 }\end{array}$ & 531 & $2.9 \pm 0.1$ & ND & $2 \pm 0.2$ & ND & ND & ND \\
\hline Rha-Rha-C10-C8 & 621 & $32.5 \pm 7.4$ & ND & $24.9 \pm 5.2$ & ND & ND & ND \\
\hline Rha-Rha-C8-C12:1 & 647 & $3.1 \pm 0.7$ & ND & $1.9 \pm 0.1$ & ND & ND & ND \\
\hline Rha-Rha-C10-C10 & 649 & $502.4 \pm 14.5$ & ND & $321.7 \pm 55.4$ & $13.2 \pm 6.3$ & $5.1 \pm 2.2$ & $41.5 \pm 12.8$ \\
\hline Rha-Rha-C10-C12:1 & 675 & $138.1 \pm 18.1$ & $3.3 \pm 0.3$ & $113.8 \pm 13.7$ & $5.5 \pm 2.2$ & $1.5 \pm 0.7$ & $16.1 \pm 5.5$ \\
\hline $\begin{array}{l}\text { Rha-Rha-C10-C12, } \\
\text { Rha-Rha-C12-C10 }\end{array}$ & 677 & $662.9 \pm 3.6$ & $13.2 \pm 1.5$ & $257.5 \pm 16.6$ & $15.4 \pm 6.3$ & $5.6 \pm 2.8$ & $56.9 \pm 19.4$ \\
\hline Rha-Rha-C12-C12:1 & 703 & $15.6 \pm 3.3$ & ND & $12.7 \pm 1.2$ & $0.9 \pm 0.5$ & $0.8 \pm 0.1$ & $3.7 \pm 1.4$ \\
\hline Rha-Rha-C12-C12 & 705 & $42.9 \pm 25.2$ & $1.7 \pm 0.2$ & $18.7 \pm 1.5$ & $2.9 \pm 0.2$ & $1.7 \pm 0.1$ & $5.3 \pm 1.7$ \\
\hline Total amount of rhamnolipids & & $1416.7 \pm 74.2$ & $18.2 \pm 2$ & $766.8 \pm 1.5$ & $37.9 \pm 15.5$ & $14.7 \pm 5.9$ & $123.5 \pm 40.8$ \\
\hline
\end{tabular}

Table 2: Rhamnolipid amounts produced by $P$. aeruginosa $\mathrm{H} 103, \mathrm{H} 636$ and $\mathrm{H} 636 \mathrm{O}$ grown to stationary phase in LB medium. ND: values not detected. Threshold: $<0.8 \times$ $10^{4} \mathrm{Area} / \mathrm{OD}_{600}{ }^{*}{ }^{*}$ Ionic species leading to LC/MS peaks.† Rhamnolipids assayed from culture supernatants. $\ddagger$ Rhamnolipids assayed from cell pellets. $†, \ddagger$ The LC/MS peak surface areas were divided by the $O D_{600}$ values of the cultures. Each value is the average of three independent experiments. 
Citation: Bouffartigues E, Gicquel G, Bazire A, Fito-Boncompte L, Taupin L, et al. (2011) The Major Outer Membrane Protein Oprf is Required for Rhamnolipid Production in Pseudomonas aeruginosa. J Bacteriol Parasitol 2:118. doi:10.4172/2155-9597.1000118

Page 4 of 5

that the rhamnolipid production is nearly abolished in the oprF mutant, which likely explains the swarming motility defect. Rhamnolipid biosynthetic genes were shown to be essential ( $r h l A)$ or important $(r h l B)$ for $P$. aeruginosa swarming $[15,20,24,37]$. The roles of HAAs (3-3-hydroxyalkanoyloxy alkanoic acids), mono-rhamnolipids and di-rhamnolipids, synthesized by RhlA, RhlB and RhlC, respectively, were dissected: di-rhamnolipids and HAAs serve as attractant and repellents, respectively, while mono-rhamnolipids act as wetting agents [42]. The impairment in rhamnolipid production of the oprF mutant could therefore explain its inability to swarm. However, restoration of the swarming phenotype was incomplete in the complemented mutant whereas rhamnolipid production reached near wild type levels. This indicated that the lack of rhamnolipid might not be the only cause of the swarming defect in the oprF mutant. Alternatively, swarming might require a rhamnolipid overproduction, which might not be achieved properly in the complemented oprF mutant.

In the oprF mutant, rhamnolipids did not accumulate intracellularly at higher levels than in the wild type strain, indicating that the production is impaired at the biosynthesis level rather than at the secretion level. This impairment can be at least in part explained by lower levels of $r h l A B$ mRNAs, suggesting an involvement of OprF in the $\operatorname{rhl} A B$ expression, which is already known to depend on a complex regulatory network [43]. Transcription of the $\operatorname{rhl} A B$ operon is under the direct control of the RhlR-RhlI quorum sensing (QS) system and of its cognate autoinducer molecule, N-butyryl-L-homoserine lactone ( $\mathrm{C}_{4}-\mathrm{HSL}$ ) [44-47] which is itself regulated by the LasR-LasI system, encoding the $\mathrm{N}$-(3-oxododecanoyl)-L-homoserine lactone auto inducer, $\left(3 \mathrm{OC}_{12}-\mathrm{HSL}\right)[48,49]$, and the MvfR-PQS (Pseudomonas Quinolone Signal) /HHQ (4-hydroxy-2-heptylquinoline) system [48]. We showed recently that QS molecule production was altered in the H636 oprF mutant since the amounts of $3 \mathrm{OC}_{12}$-HSL and $\mathrm{C}_{4}$-HSL were reduced or delayed, respectively, while that of HHQ was increased [14]. It is thus possible that these alterations in QS molecule production contribute to the observed decrease in rhlAB transcription.

It is unclear whether OprF plays a direct and/or indirect role in the observed phenotypes. The importance of OprF in stabilizing the outer membrane and maintaining the integrity of the cell wall of P. aeruginosa has been previously described $[7,8,14,29]$. A possibility is that the lack of OprF can change the cell surface and the composition of the outer membrane. Based on these considerations, the alteration of the QS and rhamnolipid production could be due to major modifications of the cell wall. The alternative possibility that the absence of OprF impairs the observed phenotypes by other means than outer membrane disorganization cannot be disregarded, considering the major role of OprF in binding interferon $\gamma$ and activation of the QS network [50]. OprF has been indeed suggested as an environmental outer membrane sensor, perceiving variations of its micro environment, and transmitting or transducing an unknown signal leading to QS activation [14,51]. Whatever the mechanisms involved linking OprF and rhamnolipid production, it is clear that the presence of OprF in the outer membrane of $P$. aeruginosa is required for environments colonization, making thus OprF a serious target for limiting $P$. aeruginosa spreading in case of cystic fibrosis.

\section{Acknowledgements}

We are grateful to R. E. W. Hancock for kindly providing $\mathrm{H} 103$ and $\mathrm{H} 636$ strains, pRW5 plasmid and monoclonal antibodies raised against OprF. We wish to thank E. Deziel for the gift of $\mathrm{PO}_{4}$ phage. The Laboratoire de Biotechnologie et Chimie Marines is supported by the Région Bretagne (France) and European FEDER. The LMDF-SME is supported by the Région Haute Normandie (financial support of G. G.), the Grand Evreux Agglomération (financial support of O. M. and of L. F. B.), the Conseil Général de l'Eure (CG27), and European FEDER funds (financial support of E. B.).

\section{References}

1. Bodey GP, Bolivar R, Fainstein V, Jadeja L (1983) Infections caused by Pseudomonas aeruginosa. Rev Infect Dis 5: 279-313.

2. Goldberg JB (2000) Pseudomonas: global bacteria. Trends Microbiol 8: 55-57.

3. Ramsey DM, Wozniak DJ (2005) Understanding the control of Pseudomonas aeruginosa alginate synthesis and the prospect for management of chronic infections in cystic fibrosis. Mol Microbiol 56: 309-322.

4. Spiers AJ, Buckling A, Rainey PB (2000) The causes of Pseudomonas diversity. Microbiology 146: 2345-2350

5. Tamber S, Hancock REW (2004) The outer membranes of Pseudomonads. In Pseudomonas, Vol. 1, pp. 575-601. Edited by J.-L. Ramos. New York, Boston, Dortrecht, Moscow: Kluver Academic/Plenum Publishers, London.

6. Nestorovich EM, Sugawara E, Nikaido H, Bezrukov SM (2006) Pseudomonas aeruginosa porin OprF: properties of the channel. J Biol Chem 281: 1623016237.

7. Woodruff WA, Hancock REW (1989) Pseudomonas aeruginosa outer membrane protein $\mathrm{F}$ : structural role and relationship to the Escherichia coll OmpA protein. J Bacteriol 171: 3304-3309.

8. Rawling EG, Brinkman FSL, Hancock REW (1998) Roles of the carboxyterminal half of $P$ seudomonas aeruginosa major outer membrane protein OprF in cell shape, growth in low-osmolarity medium, and peptidoglycan association. J Bacteriol 180: 3556-3562.

9. Guyard-Nicodème M, Bazire A, Hémery G, Meylheuc T, Mollé D, et al. (2008) Outer membrane modifications of Pseudomonas fluorescens MF37 in response to hyperosmolarity. J Proteome Res 7: 1218-1225.

10. Sriramulu DD, Lünsdorf $H$, Lam JS, Römling $U$ (2005) Microcolony formation: a novel biofilm model of Pseudomonas aeruginosa for the cystic fibrosis lung J Med Microbiol 54: 667-676.

11. Jaouen T, De E, Chevalier S, Orange N (2004) Pore size dependence on growth temperature is a common characteristic of the major outer membrane protein OprF in psychrotrophic and mesophilic Pseudomonas species. App Environ Microbiol 70: 6665-6669.

12. Azghani AO, Idell S, Bains M, Hancock REW (2002) Pseudomonas aeruginosa outer membrane protein $\mathrm{F}$ is an adhesin in bacterial binding to lung epithelial cells in culture. Microb Pathog 33: 109-114.

13. Yoon SS, Hennigan RF, Hilliard GM, Ochsner UA, Parvatiyar K, et al. (2002) Pseudomonas aeruginosa anaerobic respiration in biofilms: relationships to cystic fibrosis pathogenesis. Dev Cell 3: 593-603.

14. Fito-Boncompte L, Chapalain A, Bouffartigues E, Chaker H, Lesouhaitier O, et al (2011) Full virulence of Pseudomonas aeruginosa requires OprF. Infect Immun 79: 1176-1186.

15. Köhler T, Curty LK, Barja F, van Delden C, Pechère JC (2000) Swarming of Pseudomonas aeruginosa is dependent on cell-to-cell signaling and requires flagella and pili. J Bacteriol 182: 5990-5996.

16. Skerker JM, Berg HC (2001) Direct observation of extension and retraction of type IV pili. Proc Natl Acad Sci USA 98: 6901-6904.

17. Overhage J, Lewenza S, Marr AK, Hancock REW (2007) Identification of genes involved in swarming motility using a Pseudomonas aeruginosa PAO1 miniTn5-lux mutant library. J Bacteriol 189: 2164-2169.

18. Soberón-Chávez G, Lépine F, Déziel E (2005) Production of rhamnolipids by Pseudomonas aeruginosa. Appl Microbiol Biotechnol 68; 718-725.

19. Abdel-Mawgoud AM, Lépine F, Déziel E (2010) Rhamnolipids: diversity of structures, microbial origins and roles. Appl Microbiol Biotechnol 86: 1323-1336.

20. Caiazza NC, Shanks RM, O'Toole GA (2005) Rhamnolipids modulate swarming motility patterns of Pseudomonas aeruginosa. J Bacteriol 187: 7351-7361.

21. Al-Tahhan RA, Sandrin TR, Bodour AA, Maier RM (2000) Rhamnolipid-induced removal of lipopolysaccharide from Pseudomonas aeruginosa: effect on cell surface properties and interaction with hydrophobic substrates. Appl Environ Microbiol 66 : 3262-3268.

22. Zhong H, Zeng GM, Yuan XZ, Fu HY, Huang GH et al. (2007) Adsorption 
Citation: Bouffartigues E, Gicquel G, Bazire A, Fito-Boncompte L, Taupin L, et al. (2011) The Major Outer Membrane Protein Oprf is Required for Rhamnolipid Production in Pseudomonas aeruginosa. J Bacteriol Parasitol 2:118. doi:10.4172/2155-9597.1000118

Page 5 of 5

of dirhamnolipid on four microorganisms and the effect on cell surface hydrophobicity. Appl Microbiol Biotechnol 77: 447-455.

23. Zhong H, Zeng GM, Liu JX, Xu XM, Yuan XZ et al. (2008) Adsorption of monorhamnolipid and dirhamnolipid on two Pseudomonas aeruginosa strains and the effect on cell surface hydrophobicity. Appl Microbiol Biotechnol 79: 671 677

24. Pamp SJ, Tolker-Nielsen T (2007) Multiple roles of biosurfactants in structural biofilm development by Pseudomonas aeruginosa. J Bacteriol 189: 2531-2539.

25. Davey ME, Caiazza NC, O'Toole GA (2003) Rhamnolipid surfactant production affects biofilm architecture in Pseudomonas aeruginosa PAO1. J Bacteriol 185: 1027-1036.

26. Boles BR, Thoendel M, Singh PK (2005) Rhamnolipids mediate detachment of Pseudomonas aeruginosa from biofilms. Mol Microbiol 57: 1210-1223.

27. Alhede M, Bjarnsholt T, Jensen PØ, Phipps RK, Moser C, et al (2009) Pseudomonas aeruginosa recognizes and responds aggressively to the presence of polymorphonuclear leukocytes. Microbiology 155: 3500-3508.

28. Van Gennip M, Christensen LD, Alhede M, Phipps R, Jensen P $\varnothing$, et al (2009) Inactivation of the rhlA gene in Pseudomonas aeruginosa prevents rhamnolipid production, disabling the protection against polymorphonuclear leukocytes. APMIS 117: 537-546.

29. Woodruff WA, Hancock REW (1988) Construction and characterization of Pseudomonas aeruginosa protein F-deficient mutants after in vitro and in vivo insertion mutagenesis of the cloned gene. J Bacteriol 170: 2592-2598.

30. Brinkman FSL, Schoofs G, Hancock REW, De Mot R (1999) Influence of a putative ECF Sigma factor on expression of the major outer membrane protein OprF, in Pseudomonas aeruginosa and Pseudomonas fluorescens. J Bacteriol 181: 4746-4754

31. Rashid MH, Kornberg A (2000) Inorganic polyphosphate is needed for swimming, swarming, and twitching motilities of Pseudomonas aeruginosa. Proc Natl Acad Sci 25: 4885-4890.

32. Youssef NH, Duncan KE, Nagle DP, Savage KN, Knapp RM, et al. (2004). Comparison of methods to detect biosurfactant production by diverse microorganisms. J Microbiol Methods 56: 339-347.

33. Bazire A, Dheilly A, Diab F, Morin D, Jebbar M, Haras D, Dufour A (2005) Osmotic stress impairs production of cell-to-cell signal molecules and rhamnolipid biosurfactant by Pseudomonas aeruginosa. FEMS Microbiol Lett 253: 125-131.

34. Livak KJ, Schmittgen TD (2001) Analysis of relative gene expression data using real-time quantitative PCR and the 2(-Delta Delta C(T)) Method. Methods 25: 402-408

35. Corbella ME, Puyet A (2003) Real-time reverse transcription-PCR analysis of expression of halobenzoate and salicylate catabolism-associated operons in two strains of Pseudomonas aeruginosa. Appl Environ Microbiol 69: 22692275.

36. Bradley DE (1973). Basic characterization of a Pseudomonas aeruginosa pilusdependent bacteriophage with a long noncontractile tail. J Virol. 12: 1139-1148.

37. Déziel E, Lépine F, Milot S, Villemur R (2003) rhlA is required for the production of a novel biosurfactant promoting swarming motility in Pseudomonas aeruginosa: 3-(3-hydroxyalkanoyloxy)alkanoic acids (HAAs), the precursor of rhamnolipids. Microbiology 149: 2005-2013.

38. Zhu K, Rock CO (2008) RhIA converts $\beta$-hydroxyacyl-acyl carrie protein intermediates in fatty acid synthesis to the $\beta$-hydroxydecanoyl- $\beta$ hydroxydecanoate component of rhamnolipids in Pseudomonas aerguginosa. J Bacteriol 190: 3147-3154.

39. Rahim R, Ochsner UA, Olvera C, Graninger M, Messner P, et al. (2001) Cloning and functional characterization of the Pseudomonas aeruginosa rhIC gene that encodes rhamnosyltransferase 2 , an enzyme responsible for di-rhamnolipid biosynthesis. Mol Microbiol 40: 708-718.

40. Wilhelm S, GdyniaA, Tielen P, Rosenau F, Jaeger KE (2007) The autotransporter esterase EstA of Pseudomonas aeruginosa is required for rhamnolipid production, cell motility, and biofilm formation. J Bacteriol 189: 6695-6703.

41. Caiazza NC, Merritt JH, Brothers KM, O'Toole GA (2007) Inverse regulation of biofilm formation and swarming motility by Pseudomonas aeruginosa PA14. J Bacteriol 189: 3603-3612.

42. Tremblay J, Richardson AP, Lépine F, Déziel E (2007) Self-produced extracellular stimuli modulate the Pseudomonas aeruginosa swarming motility behaviour. Environ Microbiol 9: 2622-2630.

43. Reis RS, Pereira AG, Neves BC, Freire DM (2011) Gene regulation of rhamnolipid production in Pseudomonas aeruginosa. Bioresource Technology 102: 6377-6384.

44. Brint JM, Ohman DE (1995) Synthesis of multiple exoproducts in Pseudomonas aeruginosa is under the control of RhIR-Rhll, another set of regulators in strain PAO1 with homology to the autoinducer-responsive LuxR-Luxl family. J Bacteriol 177: 7155-7163.

45. Ochsner UA, Reiser J (1995) Autoinducer-mediated regulation of rhamnolipid biosurfactant synthesis in Pseudomonas aeruginosa. Proc Natl Acad Sci USA 92: 6424-6428.

46. Pearson JP, Pesci EC, Iglewski BH (1997) Roles of Pseudomonas aeruginosa las and $\mathrm{rhl}$ quorum-sensing systems in control of elastase and rhamnolipid biosysnthesis genes. J Bacteriol 179: 5756-5767.

47. Medina G, Juárez K, Soberón-Chávez G (2003) The Pseudomonas aeruginosa $r h / A B$ operon is not expressed during the logarithmic phase of growth even in the presence of its activator RhIR and the autoinducer N-butyryl-homoserine lactone. J Bacteriol 185: 377-380.

48. Diggle SP, Lumjiaktase P, Dipilato F, Winzer K, Kunakorn M, et al. (2006) Functional genetic analysis reveals a 2-Alkyl-4-quinolone signaling system in the human pathogen Burkholderia pseudomallei and related bacteria.Chem Biol 13: 701-710.

49. Schuster M, Greenberg EP (2006) A network of networks: quorum-sensing gene regulation in Pseudomonas aeruginosa. Int J Med Microbiol. 296: 73-81.

50. Wu L, Estrada O, Zaborina O, Bains M, Shen L, et al. (2005) Recognition of host immune activation by Pseudomonas aeruginosa. Science 309: 774-777.

51. Wagner VE, Frelinger JG, Barth RK, Iglewski BH (2006) Quorum sensing: dynamic response of Pseudomonas aeruginosa to external signals. Trends Microbiol 14: 55-58. 